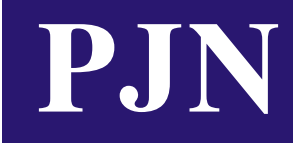

ISSN 1680-5194

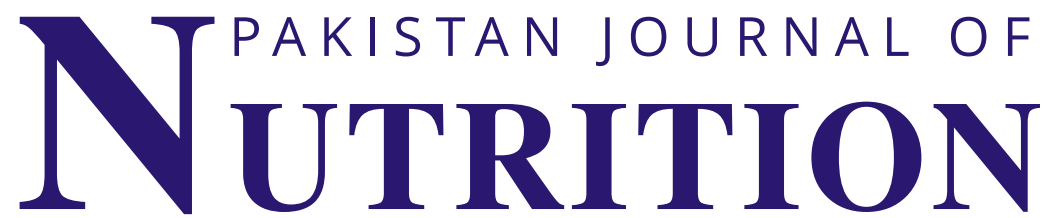

ANSI迫e佔

308 Lasani Town, Sargodha Road, Faisalabad - Pakistan Mob: +92 3003008585 , Fax: +92 418815544

E-mail: editorpjn@gmail.com 


\title{
Evaluation of Pineapple [Ananas comosus (L.) Merr] Waste Fermented Using Different Local Microorganism Solutions as Poultry Feed
}

\author{
Adrizal, Yan Heryandi, Robi Amizar and Maria Endo Mahata \\ Faculty of Animal Science, University of Andalas, Kampus Limau Manis, Padang, Indonesia
}

\section{Abstract}

Background and Objective: The utilization of pineapple waste as poultry feed is limited due to the high crude fiber and water contents and the low protein content. The crude fiber content in pineapple waste can be reduced by simple fermentation using local, naturally beneficial microorganism solutions, particularly cellulolytic microorganisms. Local microorganisms can be obtained from rice waste, bamboo sprouts, banana corms, mixed fruit waste and mixed vegetable waste. Thus, this study evaluated the nutrient content of pineapple waste, particularly crude fiber content, using submerged fermentation and different local microorganism solutions from rice waste, bamboo sprouts, banana corms, mixed fruit waste and mixed vegetable waste. Materials and Methods: This experiment was performed in a completely randomized design with two factors. The first factor was different local microorganism solutions and the second factor was the fermentation duration (1, 2 and 3 weeks). Each treatment was replicated twice. Total water, dry matter, crude protein, crude fiber, soluble protein and total sugar contents, as well as the cellulase activity were measured. Results: The results showed an association $(p<0.05)$ between the different local microorganism solutions and the fermentation durations on the crude fiber, total sugar and soluble protein contents of the pineapple waste fermentation product. Cellulose activity in pineapple waste was significantly affected by the different local microorganism solutions and the fermentation duration and the different local microorganism solutions significantly affected the crude protein, water and dry matter contents $(p<0.05)$. Conclusion: Higher total water and lower total dry matter contents of the pineapple waste fermentation product were detected using the local microorganism solution from bamboo sprouts and a higher total crude protein content were detected using the local microorganism solutions from rice waste, bamboo sprouts, mixed fruit waste and mixed vegetable waste, further a lower total crude fiber content was detected using the local microorganism solution from bamboo sprouts with a fermentation duration of 1, 2 and 3 weeks. A higher total sugar content was detected using the local microorganism solution from rice waste and a higher soluble protein content was detected using the local microorganism solution from rice waste with a fermentation duration of 1 week, using that from mixed fruit waste with a fermentation duration of 2 weeks and using that from bamboo sprouts with a fermentation duration of 3 weeks. A higher cellulase activity during pineapple waste fermentation was detected using the mixed local microorganism solutions from vegetable and mixed fruit waste. The local microorganism solution from bamboo sprouts and a fermentation duration of 1 week was the best combination for lowering the crude fiber content of pineapple waste.

Key words: Pineapple waste, local microorganism solution, pineapple waste nutrient, crude fiber, poultry feed different local microorganism solutions as poultry feed. Pak. J. Nutr., 16: 84-89.

Corresponding Author: Maria Endo Mahata, Faculty of Animal Science, University of Andalas, Kampus Limau Manis, Padang, Indonesia Tel/Fax: + 62 (751) 71464

Copyright: @ 2017 Adrizal et al. This is an open access article distributed under the terms of the creative commons attribution License, which permits unrestricted use, distribution and reproduction in any medium, provided the original author and source are credited.

Competing Interest: The authors have declared that no competing interest exists. 


\section{INTRODUCTION}

The high cost of imported feed, such as corn, soybean meal and fish meal is a significant problem faced by Indonesian poultry farmers as the price of corn feed has reached ${ }^{1}$ IDR $7000 \mathrm{~kg}^{-1}$. Therefore, poultry feed must be diversified to maintain the nutritional quality and reduce the use of imported feed.

Feed nutrients can be diversified by utilizing and processing agro-industrial waste. Our previous studies have shown that up to $20 \%$ of a juice waste mixture can be used in a broiler diet, that the nutrient quality of the juice waste mixture could be improved after 30 min of incubation in an autoclave and that as much as $40 \%$ of the juice waste mixture could be used in a broiler diet $^{2-4}$. Indonesia is the world's largest pineapple exporter and Sumatra Island and Java (Subang area) are the main pineapple [Ananas comosus (L.) Merr] producing areas. Pineapple production in Indonesia is increasing continuously, 399,299 t of pineapples were produced in 2000 and 1,540,626 t were produced ${ }^{5}$ in 2011. Lampung province is the largest pineapple producer in Sumatra Island because of the PT Great Giant Pineapple processing factory. This factory is housed next to a 32,000 ha pineapple plantation and pineapples are processed into various products, including canned pineapple. Nearly $40 \%$ of pineapples become waste after processing, which is a problem if it is allowed to accumulate. Puspitarini ${ }^{6}$ reported, that the PT Great Giant Pineapple factory produces $424 \mathrm{t}$ of pineapple skin waste daily. Pineapple waste contains $14.22 \%$ dry matter, $81.90 \%$ organic matter, $8.10 \%$ ash, $0.56 \%$ nitrogen, $3.50 \%$ crude protein, $3.49 \%$ crude lipid and $4,481.2 \mathrm{kcal} \mathrm{kg}^{-1}$ of gross energy ${ }^{7}$. Nurhayati ${ }^{8}$ revealed that pineapple skin waste contains $16.7 \%$ crude fiber content. Pineapple skin is rich in vitamin $C$ and bromelain, which hydrolyzes protein. The structure of bromelain makes it resistant to stomach acid, so up to $40 \%$ is absorbed in the digestive tract $^{9}$. Bromelain also reduces cholesterol levels as blood plasma cholesterol, triglyceride and chylomicron levels decrease in rats after they consume pineapple juice ${ }^{10}$. Supplementing a Leghorn laying hen (age, 75 weeks) diet with synthetic bromelain reduces serum levels of low-density lipoprotein and very low-density lipoprotein ${ }^{9}$. Though the cholesterol-lowering mechanism of bromelin has not been revealed, the enzyme may break the cholesterol plaque off the wall of blood vessels to improve blood circulation ${ }^{11}$. Study on the use of pineapple waste in animal feed has been previously reported by several investigators. Sumerhayati and Setyawati ${ }^{12}$ determined that pineapple waste improves the quality of tuna waste fish as poultry feed. Ningrum ${ }^{13}$ reported the effect of utilizing pineapple skin waste on the performance and digestibility of dry and organic matter in New Zealand rabbits. Furthermore, Makinde et $a / .^{14}$ found that a mixture of pineapple skin and sorghum waste can be used as animal feed. Nurhayati ${ }^{8}$ reported that supplementing yoghurt and pineapple waste in the broiler ration was improves performance of broiler. Nastiti et $a . .^{15}$ fermented pineapple skin waste using cellulolytic bacteria Actinobacillus sp., ML, which reduced the crude fiber content and increased the crude protein content.

The main problem when utilizing pineapple waste as poultry feed is the high crude fiber and water contents but the low protein content. Therefore, pineapple waste must be processed to enhance the nutritional quality before it is used in poultry feed. The crude fiber content in pineapple waste can be reduced by simple fermentation using local microorganisms. Local microorganisms are the dominant microbial population in a region/location, species differ among area/locations due to climatic effects (differences in temperature and humidity). Local microorganisms can be obtained by fermenting mixed vegetable or mixed fruit waste and adding easily digestible carbohydrates as a carbon source for the microbes. The fermentation process produces a solution that contains a mixture of naturally occurring, beneficial microorganisms, particularly cellulolytic microorganisms, which are the decomposers found in an agriculture field and use it to produce compost. The results of previous studies on formulae of local microorganisms have been reported and several types of local microorganisms are known in agriculture, such as tapai, rice, bamboo shoot, vegetable and snail local microorganisms ${ }^{16}$. However, few studies have investigated the roles of local microorganisms in poultry feed processing such as their ability to produce cellulose to degrade crude fiber. No study has reported on fermenting pineapple waste as a reliable alternative to poultry feed to reduce the egg and carcass cholesterol content in broilers.

\section{MATERIALS AND METHODS}

Pineapple waste: Fresh pineapple waste was obtained from a local market in Padang city, West Sumatra province, Indonesia and was brought to our laboratory for the experiment.

Preparation of the local microorganism solution from rice waste: Local microorganism solutions were prepared from rice 
waste by adding $500 \mathrm{~g}$ rice waste, $1 \mathrm{~L}$ fresh water and $70 \mathrm{~g}$ sugar to a plastic bowl and fermenting the mixture for 1 week. Fermentation was stopped by separating the solution by centrifugation. The resulting solution was used for pineapple waste fermentation (https://agroklinik.wordpress. com/produk/kumpulan-tentang-mol/).

Preparation of the local microorganism solution from bamboo sprouts: Bamboo sprouts (1000 g) were chopped into cubes and placed in a plastic bowl with $3 \mathrm{~L}$ water from washing the rice and $200 \mathrm{~g}$ brown sugar and this was fermented for 15 days. Fermentation was stopped by separating the solution by centrifugation. The resulting solution was used for pineapple waste fermentation (method from http://www.gerbangpertanian.com/2012/05/membuatmol-rebung-bambu.html).

\section{Preparation of the local microorganism solution from} banana corms: Banana corms (1000 g) were chopped into cubes and $2 \mathrm{~L}$ water from washing the rice and $200 \mathrm{~g}$ brown sugar were added to a plastic bowl and fermented for 15 days. Fermentation was stopped by separating the solution by centrifugation. The resulting solution was used for pineapple waste fermentation (method from https://www.youtube.com/ watch?v=0WDiS-Juh1E).

Preparation of the local microorganism solution from mixed fruit waste: Avocado, pineapple, banana, papaya, watermelon, guava and mango waste (2 $\mathrm{kg}$ of each) were chopped and mixed in a plastic bowl with $2 \mathrm{~L}$ coconut water and $200 \mathrm{~g}$ brown sugar and was fermented for 15 days. Fermentation was stopped by separating the solution by centrifugation. The resulting solution was used for pineapple waste fermentation (method from https://agroklinik.word press.com/produk/kumpulan-tentang-mol/).

Preparation of the local microorganism solution from mixed vegetable waste: Radish, horseradish mustard, kale and spinach waste (10 kg of each) were chopped and placed in a plastic bowl with $5 \% \mathrm{NaCl}$ and $10 \mathrm{~L}$ water from washing the rice and was fermented for 3 weeks. Fermentation was stopped by separating the solution by centrifugation. Two percent brown sugar solution was added. The resulting solution contained microorganisms for pineapple waste fermentation (method from https://isroi.com/2013/05/14/ mol-dari-limbah-sayuran/).
Experimental design: The experiment was performed in a two-factor, completely randomized design. The first factor was the different local microorganism solutions and the second factor was the fermentation duration (1, 2 and 3 weeks). Each treatment was replicated twice.

Pineapple waste fermentation: Pineapple waste was fermented for 1, 2 and 3 weeks by mixing $500 \mathrm{~g}$ fresh pineapple waste with $1 \mathrm{~L}$ of each of the different local microorganism solutions.

Variables: Total water, total dry matter, total crude protein, total crude fiber, total sugar and soluble protein contents, as well as cellulose activity were measured.

Data analysis: Data were statistically analyzed by analysis of variance. Differences among treatments were determined using Duncan's multiple range test ${ }^{17}$.

\section{RESULTS}

Effect on total water content: The total water content of the pineapple waste fermentation product was not affected by the association between the different local microorganism solutions and the fermentation durations but it was significantly affected $(p<0.05)$ by the different local microorganism solutions (Table 1).

Effect on total dry matter content: The total dry matter content of the pineapple waste fermentation product did not vary based on the association between the different local microorganism solutions and the fermentation durations, however, the different local microorganism solutions significantly affected the total dry matter content $(p<0.05$, Table 2).

Table 1: Total water content of the pineapple waste fermentation product (\%)

\begin{tabular}{llccc}
\hline & \multicolumn{4}{l}{ Fermentation duration (weeks) } \\
Local microorganism & - & & \\
solutions & 1 & 2 & 3 & Means \\
\hline Rice waste & 83.83 & 81.11 & 81.88 & $82.27^{\mathrm{C}}$ \\
Bamboo sprout & 85.71 & 86.34 & 86.97 & $86.34^{\mathrm{A}}$ \\
Banana corm & 83.19 & 83.04 & 82.70 & $82.98^{\mathrm{BC}}$ \\
Mixed fruit waste & 85.16 & 82.85 & 85.07 & $84.36^{\mathrm{B}}$ \\
Mixed vegetable waste & 78.94 & 79.50 & 78.88 & $79.10^{\mathrm{D}}$ \\
Means & 83.36 & 82.57 & 83.10 & 83.01 \\
SEM & 1.29 & & & \\
A-DMeans with different & superscript at the same columns are significantly \\
different (p<0.05), SEM: Standard error of the mean & &
\end{tabular}


Table 2:Total dry matter content of the pineapple waste fermentation product (\%)

\begin{tabular}{|c|c|c|c|c|}
\hline \multirow{2}{*}{$\begin{array}{l}\text { Local microorganism } \\
\text { solutions }\end{array}$} & \multicolumn{3}{|c|}{ Fermentation duration (weeks) } & \multirow[b]{2}{*}{ Means } \\
\hline & 1 & 2 & 3 & \\
\hline Rice waste & 16.17 & 18.90 & 18.12 & $17.73^{B}$ \\
\hline Bamboo sprout & 14.29 & 13.66 & 13.04 & $13.66^{\mathrm{D}}$ \\
\hline Banana corm & 16.81 & 16.96 & 17.31 & $17.03^{\mathrm{BC}}$ \\
\hline Mixed fruit waste & 14.85 & 17.15 & 14.94 & $15.64^{c}$ \\
\hline Mixed vegetable waste & 21.07 & 20.51 & 21.13 & $20.90^{A}$ \\
\hline Means & 16.64 & 17.43 & 16.90 & 16.99 \\
\hline SEM & 1.29 & & & \\
\hline
\end{tabular}

Table 3: Total crude protein content of the pineapple waste fermentation product (\%)

\begin{tabular}{llccc}
\hline Local microorganism & Fermentation duration (weeks) & \\
\cline { 2 - 4 } solutions & - & 2 & 3 & Means \\
\hline Rice waste & 4.66 & 4.52 & 5.28 & $4.82^{\mathrm{A}}$ \\
Bamboo sprout & 3.95 & 4.36 & 4.84 & $4.38^{\mathrm{A}}$ \\
Banana corm & 2.82 & 3.04 & 3.88 & $3.24^{\mathrm{B}}$ \\
Mixed fruit waste & 4.31 & 5.55 & 3.68 & $4.51^{\mathrm{A}}$ \\
Mixed vegetable waste & 5.15 & 5.22 & 5.05 & $5.14^{\mathrm{A}}$ \\
Means & 4.17 & 4.54 & 4.54 & 4.42 \\
SEM & 0.45 & & & \\
A,BMeans with different superscript at the same columns are significantly different \\
(p<0.05), SEM: Standard error of the mean
\end{tabular}

Table 4: Total crude fiber content of the pineapple waste fermentation product (\%)

\begin{tabular}{|c|c|c|c|c|}
\hline \multirow{2}{*}{$\begin{array}{l}\text { Local microorganism } \\
\text { solutions }\end{array}$} & \multicolumn{3}{|c|}{ Fermentation duration (weeks) } & \multirow[b]{2}{*}{ Means } \\
\hline & 1 & 2 & 3 & \\
\hline Rice waste & $18.71^{\text {def }}$ & $21.93^{c}$ & $20.88^{\text {cd }}$ & $20.51^{B}$ \\
\hline Bamboo sprout & $17.16^{\mathrm{fg}}$ & $17.77^{\text {efg }}$ & $16.38^{9}$ & $17.10^{\mathrm{D}}$ \\
\hline Banana corm & $25.11^{\mathrm{b}}$ & $22.19^{c}$ & $28.74^{\mathrm{a}}$ & $25.34^{\mathrm{A}}$ \\
\hline Mixed fruit waste & $18.93^{\mathrm{def}}$ & $21.56^{c}$ & $22.14^{c}$ & $20.87^{\mathrm{B}}$ \\
\hline Mixed vegetable waste & $18.42^{\mathrm{efg}}$ & $17.69^{\text {efg }}$ & $19.95^{\text {cde }}$ & $18.68^{c}$ \\
\hline Means & $19.66^{\mathrm{B}}$ & $20.23^{B}$ & $21.61^{\mathrm{A}}$ & 20.50 \\
\hline SEM & \multicolumn{3}{|l|}{0.95} & \\
\hline \multicolumn{5}{|c|}{$\begin{array}{l}\text { a-geans with different superscript at the same columns and rows are } \\
\text { significantly different }(p<0.05) \text {, A-D Means with different superscript at the same } \\
\text { columns and rows are significantly different }(p<0.05) \text {, SEM:Standard error of the } \\
\text { mean }\end{array}$} \\
\hline
\end{tabular}

Effect on total crude protein content: The total crude protein content was not affected by the association between the different local microorganism solutions and the fermentation durations but the fermentation durations significantly affected the total crude protein content $(p<0.05$, Table 3$)$.

Effect on total crude fiber content: All local microorganism solutions and fermentation durations significantly affected the total crude fiber content ( $p<0.05$, Table 4$)$.

Effect on total sugar content: The association between the different microorganism solutions and the fermentation
Table 5: Total sugar content of the pineapple waste fermentation product (ppm)

\begin{tabular}{llccc}
\hline \multirow{2}{*}{$\begin{array}{l}\text { Local microorganism } \\
\text { solutions }\end{array}$} & \multicolumn{4}{l}{ Fermentation duration (weeks) } \\
\hline Rice waste & 1 & \multicolumn{1}{l}{------------------- } & \\
Bamboo sprout & $436.27^{\mathrm{bc}}$ & $452.81^{\mathrm{a}}$ & $392.61^{\mathrm{e}}$ & $427.23^{\mathrm{A}}$ \\
Banana corm & $448.24^{\mathrm{a}}$ & $443.59^{\mathrm{ab}}$ & $345.71^{\mathrm{g}}$ & $412.51^{\mathrm{C}}$ \\
Mixed fruit waste & $449.30^{\mathrm{a}}$ & $447.34^{\mathrm{a}}$ & $361.30^{\mathrm{f}}$ & $419.31^{\mathrm{B}}$ \\
Mixed vegetable waste & $449.23^{\mathrm{a}}$ & $361.55^{\mathrm{f}}$ & $430.64^{\mathrm{C}}$ & $413.80^{\mathrm{C}}$ \\
Means & $447.89^{\mathrm{a}}$ & $289.62^{\mathrm{h}}$ & $408.81^{\mathrm{d}}$ & $382.10^{\mathrm{D}}$ \\
SEM & $446.18^{\mathrm{A}}$ & $398.98^{\mathrm{B}}$ & $387.81^{\mathrm{C}}$ & 410.99 \\
\hline
\end{tabular}

a-hMeans with different superscript at the same columns and rows are significantly different $(p<0.05), A-D$ Means with different superscript at the same columns and rows are significantly different $(p<0.05)$, SEM: Standard error of the mean

Table 6: Soluble protein content of the pineapple waste fermentation product (ppm)

\begin{tabular}{llccc}
\hline \multirow{2}{*}{$\begin{array}{l}\text { Local microorganism } \\
\text { solutions }\end{array}$} & \multicolumn{4}{l}{ Fermentation duration (weeks) } \\
\cline { 2 - 5 } & 1 & \multicolumn{1}{l}{-------------------- } & \\
\hline Rice waste & $258.19^{\mathrm{a}}$ & $242.97^{\text {cde }}$ & $246.89^{\mathrm{bc}}$ & $249.35^{\mathrm{A}}$ \\
Bamboo sprout & $200.49^{\mathrm{i}}$ & $234.57^{\mathrm{fg}}$ & $259.57^{\mathrm{a}}$ & $231.54^{\mathrm{BC}}$ \\
Banana corm & $222.43^{\mathrm{h}}$ & $237.79^{\mathrm{ef}}$ & $242.25^{\text {cde }}$ & $234.15^{\mathrm{B}}$ \\
Mixed fruit waste & $244.04^{\text {cd }}$ & $259.75^{\mathrm{a}}$ & $250.83^{\mathrm{b}}$ & $251.54^{\mathrm{A}}$ \\
Mixed vegetable waste & $229.75^{\mathrm{g}}$ & $238.34^{\text {def }}$ & $223.15^{\mathrm{h}}$ & $230.41^{\mathrm{C}}$ \\
Means & $230.98^{\mathrm{B}}$ & $242.68^{\mathrm{A}}$ & $244.54^{\mathrm{A}}$ & 239.40 \\
SEM & 7.04 & & & \\
\hline
\end{tabular}

a-Means with different superscript at the same columns and rows are significantly different $(p<0.05)$, ${ }^{A-D}$ Means with different superscript at the same columns and rows are significantly different $(p<0.05)$, SEM: Standard error of the mean

durations significantly affected the total sugar content $(p<0.05)$. All local microorganism solutions and fermentation durations significantly affected the total sugar content $(p<0.05$, Table 5$)$.

Effect on soluble protein content: The interaction between the different microorganism solutions and the fermentation durations significantly affected the total soluble protein content $(p<0.05)$. All local microorganism solutions and fermentation durations significantly affected the total soluble protein content $(p<0.05$, Table 6$)$.

Effect on cellulase activity: The interaction between the different microorganism solutions and the fermentation durations significantly affected the cellulase activity $(p<0.05)$. All local microorganism solutions and fermentation durations significantly affected the cellulase activity $(p<0.05$, Table 7).

\section{DISCUSSION}

In this experiment, the highest total water content in the pineapple waste fermentation product was obtained using the local microorganism solution from bamboo sprouts 
Table 7: Cellulase activity during pineapple waste fermentation $\left(\mathrm{U} \mathrm{mL}^{-1}\right)$ Fermentation duration (weeks)

Local microorganism

\begin{tabular}{lllll} 
solutions & 1 & 2 & 3 & Means \\
\hline Rice waste & $1.39^{\mathrm{ef}}$ & $1.21^{\mathrm{fg}}$ & $2.16^{\mathrm{b}}$ & $1.59^{\mathrm{A}}$ \\
Bamboo sprout & $1.35^{\mathrm{ef}}$ & $0.98^{\mathrm{hi}}$ & $1.55^{\mathrm{de}}$ & $1.29^{\mathrm{B}}$ \\
Banana corm & $0.83^{\mathrm{i}}$ & $1.11^{\mathrm{gh}}$ & $1.49^{\mathrm{de}}$ & $1.14^{\mathrm{C}}$ \\
Mixed fruit waste & $0.95^{\mathrm{hi}}$ & $1.76^{\mathrm{c}}$ & $2.31^{\mathrm{ab}}$ & $1.67^{\mathrm{A}}$ \\
Mixed vegetable waste & $0.91^{\mathrm{hi}}$ & $1.68^{\mathrm{cd}}$ & $2.47^{\mathrm{a}}$ & $1.69^{\mathrm{A}}$ \\
Means & $1.08^{\mathrm{C}}$ & $1.35^{\mathrm{B}}$ & $1.99^{\mathrm{A}}$ & 1.47 \\
SEM & 0.01 & & &
\end{tabular}

a-iMeans with different superscript at the same columns and rows are significantly different $(p<0.05)$, A-D Means with different superscript at the same columns and rows are significantly different $(p<0.05)$, SEM: Standard error of the mean

and the lowest occurred using the local microorganism solution from mixed vegetable waste, indicating that the microorganisms from bamboo sprouts more completely degraded pineapple waste than those from the other local microorganism solutions. The total crude protein content in the pineapple waste fermentation product was higher when pineapple waste was fermented by the local microorganism solutions from rice waste, bamboo sprouts, mixed fruit waste and mixed vegetable waste, whereas the lowest crude protein content occurred when the local microorganism solution from banana corms were used. The highest crude protein content in the pineapple waste fermentation product was predicted to be from the accumulation of microbial biomass and the extracellular enzymes produced by the microorganisms during fermentation, besides that also from non-protein nitrogen (NPN) from the plant as the material of local microorganism solution. Many studies have consistently demonstrated that plants are generally rich in NPN compounds, which are relatively high in amount in leaves and fruits ${ }^{14,18-22}$. The crude protein content in the pineapple waste fermentation product in this experiment was $5.14 \%$, which is much higher than that reported by Ginting et al?. The highest soluble protein content was found in pineapple waste fermented for 1 week by the local microorganism solution from rice, that from mixed fruits fermented for 2 weeks and that from bamboo sprouts fermented for 3 weeks. Soluble proteins are easily digested and absorbed in the gastrointestinal tract. The lowest crude fiber content in the pineapple waste fermentation product was found in different local microorganism solutions with different fermentation durations. The local microorganism solutions from rice waste fermented for 1 week, from bamboo sprouts fermented for 1,2 and 3 weeks, from mixed fruit waste fermented for 1 week and from mixed vegetable waste fermented for 1,2 and 3 weeks had the same ability to the lower crude fiber content in the pineapple waste fermentation product. The local microorganism solution from bamboo sprouts was the most effective in the lowering crude fiber content after a fermentation duration of 1 week. According to Maspary ${ }^{23}$, Azotobacter occurs in bamboo sprouts. Ahmad et al. ${ }^{24}$ reported that Azotobacter has low-tomoderate cellulolytic activity. The degradation of the crude fiber in pineapple waste produced sugar and the highest total sugar content was found in pineapple waste fermented with the local microorganism solutions from rice, bamboo sprouts, banana corms, mixed fruit waste and mixed vegetable waste for 1 week and also with the local microorganism solutions from bamboo sprouts and banana corms after 2 weeks. This result is associated with a higher crude fiber degradation rate of these microorganisms.

\section{CONCLUSION}

The association of local microorganism solutions from bamboo sprouts with a fermentation duration of 1 week was the best combination for lowering the crude fiber content of pineapple waste.

\section{SIGNIFICANCE STATEMENT}

This study is about utilizing pineapple waste through simple fermentation using different local microorganism solutions. Pineapple waste utilization as poultry feed is limited due the high crude fiber and water contents and the low protein content. Pineapple waste can be reduced by simple fermentation using local microorganisms.

\section{ACKNOWLEDGMENTS}

This study was performed as "Hibah Klaster Riset Guru Besar" project (contract No. 24/XIV/UNAND-2016, 16 May, 2016). We appreciate the Rector of Andalas University who provided us the opportunity and financial support to perform this research. We also thank to the Research Institutions and Community Service of Andalas University, which facilitated this research.

\section{REFERENCES}

1. Idris, M., 2016. Harga jagung tembus Rp 7.000/Kg, siapa yang nikmati? Detik Finance, September, 2016. http://finance. detik.com/berita-ekonomi-bisnis/d-3129584/harga-jagungtembus-rp-7000kg-siapa-yang-nikmati

2. Rizal, Y., M.E. Mahata, M. Andriani and G. Wu, 2010. Utilization of juice wastes as corn replacement in the broiler diet. Int. J. Poult. Sci., 9: 886-889. 
3. Mahata, M.E., Y. Rizal and G. Wu, 2012. Improving the nutrient quality of juice waste mixture by steam pressure for poultry diet. Pak. J. Nutr., 11: 172-175.

4. Mahata, M.E., M.J. Sasti, R.S. Aryani, Y. Rizal and G. Wu, 2013. The effect of Improved Juice Wastes Mixture (IJWM) for corn substitution on broilers' performance. Int. J. Poult. Sci., 12: 102-106.

5. PDDSIP Nenas, 2013. Informasi komoditas hortikultura pusat data dan sistem informasi pertanian. [Horticultural commodities information center for data and information systems agriculture No. 04/03/l, 25 Maret 2013]. http:// pusdatin.setjen.pertanian.go.id/tinymcpuk/gambar/file/C4 _Nenas.pdf

6. Puspitarini, M., 2014. Limbah industri nenas bisa suburkan tanah. [Pineapple industry waste could land fertilizer]. http:// news.okezone.com/read/2014/11/17/65/1066622

7. Ginting, S.P., R. Krisnan and K. Simanihuruk, 2005. [The substitution of forages with pineapple wastes in complete feed for goats]. Proceedings of the National Seminar of Animal Science Technology and Veteriner, September 12-13, 2005, Indonesia, pp: 604-615.

8. Nurhayati, 2013. [Broiler chicken performance feed ration containing pineapple peel meal and supplemented by yoghurt]. J. Agripet, 13: 15-20.

9. Lien, T.F., Y.H. Cheng and C.P. Wu, 2012. Effects of supplemental bromelain on egg production and quality, serum and liver traits of laying hens. J. Anim. Sci. Adv., 2: 386-391.

10. Daher, C., J. Abou-Khalil and G. Baroody, 2005. Effect of acute and chronic grapefruit, orange and pineapple juice intake on blood lipid profile in normolipidemic rat. Med. Sci. Monit., 11: 465-472.

11. Kelly, G.S., 1996. Bromelain: A literature review and discussion of its therapeutic applications. Altern. Med. Rev., 1: 243-257.

12. Sumerhayati, S. and S.J. Setyawati, 2005. [The potency of pineapple waste to increase the quality of Tuna fish waste for poultry feedstuffs]. Anim. Prod., 10: 174-178.

13. Ningrum, F.R., 2010. Pengaruh penggunaan kulit nanas terhadap kecernaan bahan kering dan bahan organik ransum kelinci New Zealand white Jantan. [The effect of ananas skin in ration on white male New Zealand rabbit performance]. Sebelas Maret University, Surakarta, Indonesia.
14. Makinde, O.A., S.M. Odeyinka and S.K. Ayandiran, 2011. Simple and quick method for recycling pineapple waste into animal feed. Livest. Res. Rural Dev., Vol. 23.

15. Nastiti, U.N., N.D.R. Lastuti and T. Nurhajati, 2013. The decreasing of crude fiber and the increasing of crude protein content of pineapple peel (Ananas comosus L. Merr) which fermented by cellulolytic bacteria (Actinobacillus sp. ML-08). Agroveteriner, 1: 46-54.

16. Agroklinik, 2016. Kumpulan tentang MOL [Collection of local microorganisms]. August 27, 2016. https://agroklinik. wordpress.com/produk/kumpulan-tentang-mol/

17. Steel, R.G.D. and J.H. Torrie, 1990. Principal and Procedures of Statistics: A Biometrical Approach. 3nd Edn., McCraw Hill Book Co., New York.

18. Milton, K. and F.R. Dintzis, 1981. Nitrogen-to-protein conversion factors for tropical plant samples. Biotropica, 13: 177-181.

19. Sedinger, J.S., 1984. Protein and amino acid composition of tundra vegetation in relation to nutritional requirements of geese. J. Wildlife Manage., 48: 1128-1136.

20. Izhaki, I., 1993. Influence of nonprotein nitrogen on estimation of protein from total nitrogen in fleshy fruits. J. Chem. Ecol., 19: 2605-2615.

21. Conklin-Brittain, N.L., E.S. Dierenfeld, R.W. Wrangham, M. Norconk and S.C. Silver, 1999. Chemical protein analysis: A comparison of Kjeldahl crude protein and total ninhydrin protein from wild, tropical vegetation. J. Chem. Ecol., 25: 2601-2622.

22. Levey, D.J., H.A. Bissell and S.F. O'keefe, 2000. Conversion of nitrogen to protein and amino acids in wild fruits. J. Chem. Ecol., 26: 1749-1763.

23. Maspary, 2012. Apa kehebatan MOL bonggol pisang? [What greatness banana corm local microorganisms]. May 26, 2012. http://www.gerbangpertanian.com/2012/05/apa-kehebatanmol-bonggol-pisang.html

24. Ahmad, B., S. Nigar, N.A. Malik, S. Bashir and J. Ali et al., 2013. Isolation and characterization of cellulolytic nitrogen fixing Azotobacter species from wheat rhizosphere of Khyber Pakhtunkhwa. World Applied Sci. J., 27: 51-60. 